\section{Tomato Spotted Wilt Virus-resistant Fresh-market Tomato Breeding Lines: NC 58S, NC 123S, NC 127S, and NC 132S}

\author{
Randy G. Gardner and Dilip R. Panthee ${ }^{1}$ \\ Department of Horticultural Science, North Carolina State University, \\ Mountain Horticultural Crops Research and Extension Center (MHCREC), \\ 455 Research Drive, Mills River, NC 28759-3423
}

Additional index words. fusarium wilt, marker assisted selection, root knot nematodes, $S w-5$ gene, verticillium wilt

NC 58S, NC 123S, NC 127S, and NC 132S are fresh-market tomato (Solanum lycopersicum L.) breeding lines that have the single dominant gene $S w-5$ for resistance to tomato spotted wilt virus (TSWV) along with other important disease resistance genes. They are useful as parents in developing multiple disease-resistant tomato hybrids.

\section{Origin}

All four breeding lines were developed by selfing the $F_{1}$ hybrid 'Amelia', which is a codeveloped hybrid resulting from the cross of a proprietary Clause Seed Co. inbred line with NC 111F-2 (98). Both parents of 'Amelia' contribute the $\mathrm{Ve}$ gene for resistance to verticillium wilt (Verticillium dahlia $\mathrm{Kleb}$ ) and the $I$ and $I-2$ genes for resistance to races 1 and 2 of fusarium wilt [Fusarium oxysporium f.sp. lycopersici (Sacc.) W.C. Snyder and H.N. Hans]. The Clause line has the $S w-5$ gene for resistance to TSWV and the $M i$ gene for resistance to root knot nematodes (Meloidogyne spp). NC $111 \mathrm{~F}-2$ (98) has the $I-3$ gene for resistance to fusarium wilt race 3 .

Tissue samples from $196 \mathrm{~F}_{2}$ generation seedlings of 'Amelia' selfed were tested for molecular markers tightly linked to the $S w-5$ gene. From fruit of the $196 \mathrm{~F}_{2}$ plants grown to maturity in the greenhouse at Mills River, $\mathrm{NC}$, seed were saved from 30 selections indicated homozygous for the $S w-5$ gene by the molecular marker test and having the most desirable horticultural traits. The 30 selections chosen for further evaluation and selection were also tested for molecular markers linked to the $M i$ gene for root knot nematode resistance and the $I-3$ gene for fusarium wilt race 3 resistance. Replicated plots of the $F_{3}$

Received for publication 16 Nov. 2011. Accepted for publication 3 Jan. 2012.

The tomato breeding program of North Carolina State University was supported by the North Carolina Tomato Growers Association and the Hatch project of USDA.

Assistance of Dr. Mikel Stevens in screening the $\mathrm{F}_{2}$ population with molecular markers for the $\mathrm{Sw}-5$ gene is greatly appreciated.

${ }^{1}$ To whom reprint requests should be addressed; e-mail Dilip_panthee@ncsu.edu. generation were grown in two growers' fields in coastal South Carolina in 2001 under conditions of heavy natural infection by TSWV to verify homozygous resistance to TSWV conferred by the $S w-5$ gene. Additional $\mathrm{F}_{3}$ generation plots were grown at Mills River in 2001 and selected for desirable plant and fruit traits. Additional selection and testing for TSWV resistance was repeated in field trials in coastal South Carolina and at Mills River in 2002. In the fall of 2002, hybrids were made with promising selections using NC 84173PVP as a test parent. The $\mathrm{F}_{1}$ hybrids and the TSWVresistant parent lines were evaluated in coastal South Carolina and at Mills River, NC, in 2003 and in subsequent years. Verification of fusarium wilt race 3 resistance in lines having the marker linked to the $I-3$ gene was done using the seedling root dip method in a growth chamber. Hybrids made with the lines were also evaluated for fusarium wilt race 3 and root knot nematode resistances in heavily infested growers' fields in Polk County, NC.

Based on performance of lines and their $\mathrm{F}_{1}$ hybrids, advanced inbred selections designated as NC 58S, NC 123S, NC 127S, and NC 132S were chosen for release as finished tomato breeding lines. Single plant selections of all of the lines were made through the $\mathrm{F}_{5}$ generation, and bulking of seed of the individual selections was done in subsequent generations. Repeated testing of the four lines for molecular markers linked to the $S w-5$ (Robbins et al., 2010), I-3, and Mi genes has been conducted (Panthee and Foolad, 2012).

\section{Description}

A wide range of plant and fruit types in segregating generations derived from the 'Amelia' $F_{1}$ hybrid provided for diversity of fruit size and shape, maturity, plant vigor, and other horticultural traits. The four lines were compared with 'Mountain Spring' (Gardner, 1992) in replicated trials in 2004 (Table 1). None of the four lines differed from 'Mountain Spring' in total yield, marketable yield, or percent marketable grade yield; $\mathrm{NC} 123 \mathrm{~S}$ and NC $127 \mathrm{~S}$ were similar in maturity to 'Mountain Spring', whereas NC 58S and NC $132 \mathrm{~S}$ were later in maturity than 'Mountain Spring' as indicated by the yield during the first 2 weeks of harvest (Table 1). All four lines were smaller fruited than 'Mountain Spring' but did not differ in fruit size among the lines.

NC 123S has a tall determinate plant with fairly open growth habit and dark green, noncurled foliage. Fruit are deep oblate and are smooth and symmetrical in shape. Immature fruit have a uniform green color ( $u$ gene) and have jointed pedicels. Fruit ripen to a bright red external and internal color. Ripe fruit are firm and have shown good resistance to fruit cracking and weather check. In addition to $S w-5$, NC $123 \mathrm{~S}$ has the Ve, I, I-2, I-3, and Mi resistance genes. $\mathrm{NC} 123 \mathrm{~S}$ is used as a parent in the $\mathrm{F}_{1}$ hybrid 'Crista' $(\mathrm{NC} 123 \mathrm{~S} \times \mathrm{NC} 84173$ $\mathrm{PVP}$ ), which is marketed by Harris Moran. NC $123 \mathrm{~S}$ is also used as a parent in the recently released $\mathrm{F}_{1}$ hybrid 'Mountain Merit' (NC 1 CELBR $\times$ NC 123S) (Panthee and Gardner, 2010), which is produced by Bejo Seed Co.

NC 58S and NC 132S have medium-sized determinate plants with fairly concentrated fruit set. Both lines have slight adaxial leaf curl in association with the nippled blossom ( $n$ gene). Fruit of both lines are deep oblate in shape and are smooth with pinpoint blossom scars conditioned by the $n$ gene. Fruit ripen to a uniform bright red exterior and interior color and are firm and highly resistant to fruit cracking and weather check. Immature fruit of both have uniform light green color $(u$ gene) and have jointed pedicels. In addition to $S w-5$, NC $58 \mathrm{~S}$ has the $V e, I$, and $I-2$ genes. $\mathrm{NC} 58 \mathrm{~S}$ is used as a parent in the $\mathrm{F}_{1}$ hybrid 'Mountain Glory' (NC 58S × NC 84173 PVP), which is marketed by Syngenta. 'Mountain Glory' is very similar in plant and fruit type to 'Mountain Spring' (R.G. Gardner, personal observations) and is widely used as a replacement for 'Mountain Spring' in tomatogrowing areas where TSWV is a problem. NC $132 \mathrm{~S}$ has the $V e, I, I-2$, and $M i$ genes in addition to $S w-5$. NC $132 \mathrm{~S}$ is a parent in the $\mathrm{F}_{1}$ hybrid 'Fletcher' (NC 132S × NC 84173 PVP), which is marketed by Seedway. 'Fletcher' is very similar to 'Mountain Spring' in plant and fruit type but has the additional advantages of being resistant to TSWV and root knot nematodes.

$\mathrm{NC} 127 \mathrm{~S}$ has a medium-sized determinate plant with non-curled leaf type. Foliage is fairly heavy providing good fruit coverage. Fruit are deep oblate in shape and are smooth with normal, stellate blossom end scars. Fruit develop bright red exterior and interior color and are firm in the ripe stage. Immature fruit have uniform light green color ( $u$ gene), and fruit pedicels are jointed. $\mathrm{NC} 127 \mathrm{~S}$ has shown good combining ability as a parent in experimental $F_{1}$ hybrids and has produced hybrids with high fruit yield. In addition to $S w-5$, NC $127 \mathrm{~S}$ has the $V e, I$, and $I-2$ resistance genes.

Color images of the four breeding lines and additional information regarding them are available at the following web site: $<\mathrm{http}: /$ www.ces.ncsu.edu/fletcher/programs/tomato/ releases/seedlines.html $>$.

\section{Use}

$\mathrm{NC} 58 \mathrm{~S}, \mathrm{NC} 123 \mathrm{~S}, \mathrm{NC} 127 \mathrm{~S}$, and $\mathrm{NC}$ $132 \mathrm{~S}$ have been widely distributed to other 
Table 1. Fruit yield and size of NC 58S, NC 123S, NC 127S, and NC 132S TSWV-resistant tomato breeding lines compared with 'Mountain Spring'.

\begin{tabular}{lccccc}
\hline Genotype & $\begin{array}{c}\text { Early yield } \\
\left(\mathrm{t} \cdot \mathrm{ha}^{-1}\right)^{\mathrm{y}}\end{array}$ & $\begin{array}{c}\text { Total yield } \\
\left(\mathrm{t} \cdot \mathrm{ha}^{-1}\right)^{\mathrm{x}}\end{array}$ & $\begin{array}{c}\text { Marketable yield } \\
\left(\mathrm{t} \cdot \mathrm{ha}^{-1}\right)^{\mathrm{x}}\end{array}$ & $\begin{array}{c}\text { Marketable } \\
(\%)^{\mathrm{x}}\end{array}$ & $\begin{array}{c}\text { Avg fruit wt } \\
(\mathrm{g} / \text { fruit })^{\mathrm{x}}\end{array}$ \\
\hline Mountain Spring & 35 & 108 & 72 & 67 & 313 \\
NC 58S & 23 & 103 & 72 & 70 & 237 \\
NC 123S & 28 & 109 & 76 & 70 & 249 \\
NC 127S & 37 & 126 & 88 & 64 & 240 \\
NC 132S & 20 & 100 & 64 & 11 & 261 \\
Least significant & 8 & 21 & 24 & & 27 \\
$\quad$ difference \\
\hline
\end{tabular}

${ }^{2}$ Data are the average of early and late vine-ripe trials at Mills River, NC, in 2004.

${ }^{y}$ Average of two replications from first three harvests.

${ }^{\mathrm{x}}$ Average of two replications from total harvests.

tomato breeders, and three of them are already used as parents in commercial hybrids as indicated previously. NC 123S, in particular, is useful because of its combined resistance to verticillium wilt, all three races of fusarium wilt, TSWV, and root knot nematodes. All four lines should be useful as parents in additional $F_{1}$ hybrids and as sources of disease seed transfer agreement, which can be downloaded with instructions for submission at the following website: $<$ http://www.ces.ncsu.edu/ fletcher/programs/tomato/releases/index. html>.

\section{Literature Cited}

Gardner, R.G. 1992. Mountain Spring tomatoNC-8276 and NC-84173 tomato breeding lines. HortScience 27:1233-1234.

Panthee, D.R. and M.R. Foolad. 2012. A Reexamination of molecular markers for use in markerassisted breeding in tomato. Euphytica 184: 165-179.

Panthee, D.R. and R.G. Gardner. 2010. 'Mountain Merit': A late blight-resistant large-fruited tomato hybrid. HortScience 45:1547-1548.

resistance genes and desirable horticultura traits in developing other fresh-market tomato breeding lines.

\section{Availability}

Distribution of seed of NC 58S, NC 123S, $\mathrm{NC} 127 \mathrm{~S}$, and $\mathrm{NC} 132 \mathrm{~S}$ requires a signed
Robbins, M.D., M.A.T. Masud, D.R. Panthee, R.G. Gardner, D.M. Francis, and M.R. Stevens. 2010. Marker-assisted selection for coupling phase resistance to tomato spotted wilt virus and Phytophthora infestans (late blight) in tomato. HortScience 45:1424-1428. 